\title{
Influence of temperature on denitrification of an industrial high-strength nitrogen wastewater in a two-sludge system
}

\author{
J Carrera*, T Vicent and FJ Lafuente \\ Department of Chemical Engineering, Universitat Autònoma de Barcelona, 08193 Bellaterra, Spain
}

\begin{abstract}
The temperature effect on denitrification rate of a two-sludge system has been studied. An industrial high-strength wastewater and an industrial by-product containing mainly methanol, as external carbon source, were used in this study. The maximum denitrification rate (MDR) was determined at six different temperatures: $6,8,10,15,20$ and $25^{\circ} \mathrm{C}$ in batch mode. The temperature coefficient was found to be $1.10 \pm 0.01$ at temperatures between 10 to $25^{\circ} \mathrm{C}$ and $1.37 \pm 0.01$ at temperatures between 6 to $10^{\circ} \mathrm{C}$. The MDR obtained in the two-sludge system $\left(0.28 \mathrm{mg} \mathrm{N} \cdot \mathrm{mg} \mathrm{VSS}^{-1} \cdot \mathrm{d}^{-1}\right.$ at $\left.25^{\circ} \mathrm{C}\right)$ was higher than the one obtained in a single-sludge system with a similar external carbon source. The $\mathrm{COD} / \mathrm{N}$ ratio required for complete denitrification in the two-sludge system was approximately stoichiometric, which is $3.7 \pm 0.9 \mathrm{mg} \mathrm{COD} \cdot \mathrm{mg} \mathrm{N}^{-1}$.
\end{abstract}

\section{Introduction}

Generally, an excess of nitrates in water is related to public health diseases like methemoglobinemia and carcinogenesis. Therefore, drinking water should not contain more than $10 \mathrm{mg} \mathrm{NO}-\mathrm{N} \cdot \ell^{-1}$ (EPA, 1993). For this reason, the removal of nitrates from wastewater is necessary. There are three main methods to remove nitrates from wastewater: ion exchange, reverse osmosis and biological denitrification. Ion exchange is limited due to the lack of resins with high selectivity for nitrate and the problem of regenerating them. The problem of reverse osmosis is low selectivity of the membranes used for nitrate. Due to these limitations for removal of nitrates from industrial wastewater, the most versatile and widely used technology is biological denitrification (Mateju et al., 1992).

The bacteria responsible for the denitrification are classified as facultative heterotrophs and are able to use nitrate as an acceptor of electrons, transforming it into nitrogen gas. During the process, electrons are transferred from a donor, normally an organic substrate, to an acceptor, nitrate or nitrite. Practically any organic compound that can be biologically degraded under aerobic conditions can be used for denitrification. However, denitrification rates will be different depending on the organic compound used.

Denitrification is determined by the stoichiometric ratio between the organic compound used and the nitrate. Industrial wastewater may not offer the appropriate $\mathrm{COD} / \mathrm{N}$ ratio for carrying out the denitrification process. In order to treat industrial wastewater with a low $\mathrm{COD} / \mathrm{N}$ ratio it is necessary to add an external organic carbon source. Different external carbon sources are used for denitrification: glucose (Chevron et al., 1997), saccharose (Sison et al., 1995), acetic acid (Oh and Silverstein, 1999), lactic acid (Akunna et al., 1993), ethanol (Hasselblad and Hallin, 1998; Nyberg et al., 1996) and methanol (Bailey et al., 1998; Bilanovic et al., 1999).

Different criteria have been used to choose a specific external carbon source for the denitrification process. First, it is necessary to consider which carbon compound yields the fastest denitrification rate. Published references give conflicting results. Some authors

\footnotetext{
* To whom all correspondence should be addressed.

푱34-93-5812141; fax 34-93-5812013; e-mail: julian.carrera@uab.es Received 28 May 2002; accepted in revised form 29 October 2002.
}

suggest that acetic acid achieves greater rate than glucose, methanol or ethanol (Constantin and Fick, 1997). However, other authors showed similar results with denitrification on acetic acid to those achieved with methanol (Nyberg et al., 1992). Several references indicate that ethanol reaches higher rate than methanol (Andersson et al., 1998; Christensson et al., 1994), although another study indicates that the rate with methanol is greater than that with ethanol (Henze, 1991).

It is also necessary to consider the costs and availability of the external carbon source. If the source is a pure chemical compound (ethanol, methanol, acetic acid), it will be available at a market price. An alternative is to use a by-product as the carbon source, for example the sludge produced in the process. However, the organic matter coming from the sludge is not very biodegradable and therefore a previous chemical or thermal hydrolysis is required. This procedure adds extra cost to the process (Barlindhaug and Odegaard, 1996).

To build an industrial scale denitrification plant, the external carbon source should be cheap and available to guarantee the continuous operation of the wastewater treatment plant. These requirements can be achieved using industrial by-products. In the present study, the feasibility to use a by-product as an external carbon source for the denitrification process was evaluated. This by-product is mainly methanol and the rest is acetone and isopropilic alcohol.

The temperature effect on the denitrification rate is another important feature in the design of a denitrification process. This effect is commonly described using an Arrhenius-type equation (Orhon et al., 2000):

$$
r_{D, T 1}=r_{D, T 2} \cdot \theta^{(T 1-T 2)}
$$

where:

$$
\begin{aligned}
r_{D, T i}= & \text { denitrification rate at temperature } T i, \\
& \mathrm{mg} \mathrm{N}_{-\mathrm{NO}_{3}} \cdot \mathrm{mg} \mathrm{VSS}^{-1} \cdot \mathrm{d}^{-1} \\
\theta= & \text { temperature coefficient }
\end{aligned}
$$

The interest in this topic is reflected in the number of published results on the determination of the effect of temperature on the 


\begin{tabular}{|c|c|c|c|c|}
\hline \multicolumn{5}{|c|}{$\begin{array}{c}\text { TABLE } 1 \\
\text { Temperature coefficients for different systems }\end{array}$} \\
\hline $\begin{array}{l}\text { Temperature } \\
\text { coefficient }\end{array}$ & Technology & $\begin{array}{l}\text { Carbon } \\
\text { source }\end{array}$ & $\begin{array}{l}\text { Range of } \\
\text { tempera- } \\
\text { tures }\left({ }^{\circ} \mathrm{C}\right)\end{array}$ & Reference \\
\hline$\frac{1.06}{1.06}$ & Single-sludge & $\frac{\text { Methanol }}{\text { Ethanol }}$ & $7-17$ & Nyberg et al. (1996) \\
\hline 1.06 & Single-sludge & $\begin{array}{l}\text { Hydrolysed } \\
\text { sludge }\end{array}$ & - & $\begin{array}{l}\text { Barlindhaug and } \\
\text { Odegaard (1996) }\end{array}$ \\
\hline $\begin{array}{l}1.06 \\
1.30\end{array}$ & Single-sludge & - & $\begin{array}{l}7-15 \\
2-7\end{array}$ & $\begin{array}{l}\text { Oleszkiewicz and } \\
\text { Berquist (1988) }\end{array}$ \\
\hline$\frac{1.11}{1.12}$ & $\begin{array}{l}\text { Denitrifying } \\
\text { pure culture }\end{array}$ & $\frac{\text { Methanol }}{\text { Ethanol }}$ & $15-25$ & $\begin{array}{l}\text { Christensson et al. } \\
\text { (1994) }\end{array}$ \\
\hline 1.13 & $\begin{array}{l}\text { Denitrifying } \\
\text { pure culture }\end{array}$ & Methanol & $6-30$ & $\begin{array}{l}\text { Timmermans and } \\
\text { Van Haute (1983) }\end{array}$ \\
\hline
\end{tabular}

\begin{tabular}{|c|c|}
\hline \multicolumn{2}{|c|}{$\begin{array}{c}\text { TABLE } 2 \\
\text { Composition of industrial } \\
\text { wastewater after the } \\
\text { nitrification process }\end{array}$} \\
\hline Component & $\begin{array}{c}\text { Concentration } \\
\left(\mathrm{mg} \cdot \ell^{-1}\right)\end{array}$ \\
\hline COD & 0 \\
\hline $\mathrm{N}^{-\mathrm{NO}_{3}^{-}}$ & 700-1900 \\
\hline $\mathrm{N}-\mathrm{NH}_{4}^{+}$ & $0-10$ \\
\hline $\mathrm{F}^{-}$ & $10-20$ \\
\hline $\mathrm{Cl}^{-}$ & $1000-1500$ \\
\hline $\mathrm{SO}_{4}^{2-}$ & $5000-10000$ \\
\hline
\end{tabular}

denitrification process. In Table 1 some of the different references are summarized but the results are mainly for single-sludge systems or pure denitrifying cultures. There is a lack of data on temperature coefficients for a two-sludge system. This paper focuses on the determination of temperature coefficients of a two-sludge system using a wide range of temperatures.

\section{Experimental}

\section{Biomass and two-sludge system}

The denitrifying biomass comes from a two-sludge pilot plant with separate nitrification and denitrification stages. The industrial wastewater, with $5000 \mathrm{mg} \mathrm{N}-\mathrm{NH}_{4}^{+} \cdot \ell^{-1}$, is fed into the nitrification stage, which is made up of a $27 \ell$ aerobic reactor and a settler. Each mechanical unit of the pilot-plant (pumps, level detectors, etc.) is controlled by a PC through a data acquisition card that allows automation of all those elements. Every reactor has in-line sensors (dissolved oxygen (DO), $\mathrm{pH}, \mathrm{ORP}$, temperature) connected to probe controllers. The effluent of the nitrification stage and the external carbon source form the influents for the denitrification stage. The external carbon source is needed to denitrify the entire nitrate that has been formed. The denitrification stage is made up of a $27 \ell$ anoxic reactor; a 15 laerated tank and a settler. The nitrogen gas formed in the anoxic reactor is stripped in the aerated tank, enhancing the sedimentation in the settler.

The effect of temperature on the denitrification rate was studied in batch using biomass sampled from the denitrification system of the pilot plant. Prior to this study, the pilot plant was run on the external carbon source for more than $150 \mathrm{~d}$ and the biomass was therefore adapted to it (Carrera, 2001).

\section{Industrial wastewater}

Table 2 shows the basic composition of the industrial wastewater entering the denitrification stage. As can be seen, the nitrate concentration is 700 to $1900 \mathrm{mg} \mathrm{N}-\mathrm{NO}_{3} \cdot \ell^{-1}$ and the ammonium concentration is 0 to $10 \mathrm{mg} \mathrm{N}-\mathrm{NH}_{4}^{+} \cdot \ell^{-1}$. The industrial wastewater contains high concentrations of chloride and sulphate and does not contain organic matter.

\section{External carbon source}

A by-product of an industrial process was used as an external carbon source. The by-product is discharge from a chemical plant, made up of a mixture of methanol, isopropilic alcohol and acetone. The percentage composition is: $60 \%$ methanol, $10 \%$ acetone, $10 \%$ isopropilic alcohol and $20 \%$ water. Throughout this study, this byproduct is referred to as the 'methanol mixture'.

\section{Laboratory equipment}

The batch experiments were done using a Braun Biostat ${ }^{\circledR}-\mathrm{Q}$ fermentor unit. Figure 1 shows a diagram of the laboratory equipment. This equipment consists of four $0.5 \ell$ reactors. Each reactor has an independent system for control and measurement of temperature, $\mathrm{pH}$, stirring and dissolved oxygen (DO). An external refrigeration system was used to obtain temperatures below $15^{\circ} \mathrm{C}$.

\section{Experimental procedure}

The maximum denitrification rate (MDR) was evaluated with six experiments at different temperatures: $6,8,10,15,20$ and $25^{\circ} \mathrm{C}$. Four batch runs were carried out at each temperature (Table 3 ). The duration of each run was $24 \mathrm{~h}$ and $\mathrm{pH}$ was maintained between 8.0 and 8.5. The biomass of the Biostat ${ }^{-}-\mathrm{Q}$ was replaced with fresh biomass from the denitrifying reactor of the pilot plant in each experiment. The runs were operated with no organic matter or nitrate limitations. Nitrate, COD and VSS concentrations were measured at the end of each run. The nitrite concentration was measured twice in each run to ensure that there was no accumulation. The concentration of nitrite was practically zero in all the runs. The MDR of each run was calculated as:

$$
M D R=\frac{\left\lfloor N-\mathrm{NO}_{3}^{-}\right\rfloor_{0 h}-\left\lfloor N-\mathrm{NO}_{3}^{-}\right\rfloor_{24 h}}{[\mathrm{VSS}]_{\text {average }}}
$$

\section{Analytical methods}

The analyses of volatile suspended solids (VSS) were done using 
the methodology described in Standard Methods (1995). The analyses of nitrite $\left(\mathrm{NO}_{2}^{-}\right)$, nitrate $\left(\mathrm{NO}_{3}^{-}\right)$, chloride $\left(\mathrm{Cl}^{-}\right)$and sulphate $\left(\mathrm{SO}_{4}^{2-}\right)$ were done by capillary electrophoresis using a WATERS Quanta4000ECE. The electrolyte used was a WATERS commercial solution. The conditions of the analysis were: temperature of $20^{\circ} \mathrm{C}$, $15 \mathrm{kV}$ from a negative source, indirect UV detection at $254 \mathrm{~nm}$ and 5 min of retention time.

\section{Results and discussion}

Table 3 shows the results of the four runs carried out at each temperature. The range of denitrification rate varied between $0.28 \mathrm{mg} \mathrm{N} \cdot \mathrm{mg} \mathrm{VSS} \mathrm{VS}^{-1} \cdot \mathrm{d}^{-1}$ at $25^{\circ} \mathrm{C}$ to $0.02 \mathrm{mg} \mathrm{N} \cdot \mathrm{mg} \mathrm{VSS}^{-1} \cdot \mathrm{d}^{-1}$ at $6^{\circ} \mathrm{C}$. These denitrification rates were compared to published results obtained with methanol as external carbon source and are presented in Table 4 . The range of denitrification rates in the literature is quite large but all the results, except the pure cultures, are lower than the ones obtained in this study.

The experimental value of the $\mathrm{COD} / \mathrm{N}$ ratio consumed was calculated as:

$$
\frac{C O D}{N}=\frac{[C O D]_{o h}-[C O D]_{24 h}}{\left[N-N_{3}^{-}\right]_{0 h}-\left[N-N_{3}^{-}\right]_{24 h}}
$$

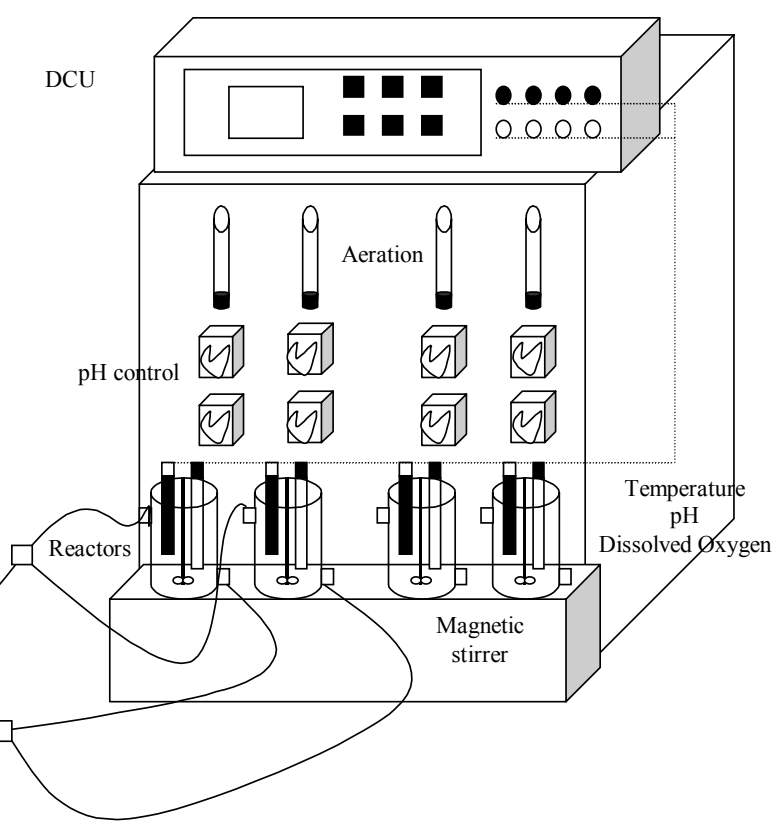

Figure 1

Diagram of the laboratory equipment
The average value was $3.7 \pm 0.9 \mathrm{mg}$ COD $\cdot \mathrm{mg} \mathrm{N}^{-1}$. This is close to the stoichiometric ratio proposed for the denitrification process using methanol as carbon source (EPA, 1993; Mateju et al. 1992); although this carbon source is not pure methanol, but a mixture of methanol, acetone and isopropilic alcohol. Nevertheless, other authors found higher experimental denitrification ratios with methanol: $4.6 \mathrm{mg} \mathrm{COD} \cdot \mathrm{mg} \mathrm{N}^{-1}$ (Bilanovic et al., 1999) or 4.45 $\mathrm{mg}$ COD·mg N $\mathrm{N}^{-1}$ (Christensson et al., 1994).

Figure 2 shows the experimental data at six different temperatures and the line of the best fit for the Arrhenius-type equation for the MDR. The influence of temperature depends on the interval of temperatures. The temperature coefficient is $1.10 \pm$ 0.01 between 10 to $25^{\circ} \mathrm{C}$, while the coefficient is $1.37 \pm 0.01$ between 6 to $10^{\circ} \mathrm{C}$.

The temperature coefficient for a single-sludge system is generally 1.06 in a range of temperatures from 7 to $17^{\circ} \mathrm{C}$ and does not depend upon the carbon source used (Table 1). On the other hand, the temperature coefficient for systems with pure denitrifying biomass is 1.13 for a range of temperature between 6 to $30^{\circ} \mathrm{C}$. Once again, this does not depend upon the carbon source used (Table 1). These values indicate that the effect of temperature on denitrification is more pronounced with pure microbial populations.

The coefficient found by this study for a range of temperatures from 10 to $25^{\circ} \mathrm{C}$ is closer to the values obtained in systems with pure denitrifying biomass. The coefficient found for temperatures between 6 and $10^{\circ} \mathrm{C}$ is 1.37 , slightly higher than the one given by Oleszkiewicz and Berquist (1988) in a single-sludge system for a range of temperatures from 2 to $7^{\circ} \mathrm{C}$. For Oleszkiewicz and Berquist, the change in the temperature coefficient value occurs around $7^{\circ} \mathrm{C}$. In this study, this change occurs around $10^{\circ} \mathrm{C}$ (Fig. 2).

The effect of temperature on the denitrification rate is important in the design of denitrifying reactors. For example, in denitrifying reactors for the treatment of industrial wastewaters, the hydraulic retention time (HRT) will be a function of the nitrogen removed,

\begin{tabular}{|c|c|c|c|c|}
\hline \multicolumn{5}{|c|}{$\begin{array}{c}\text { TABLE } 4 \\
\text { Maximum denitrification rates with methanol as carbon source }\end{array}$} \\
\hline Technology & Process & $\begin{array}{l}\text { Tempera- } \\
\text { ture }\left({ }^{\circ} \mathrm{C}\right)\end{array}$ & 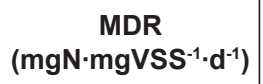 & Reference \\
\hline Single-sludge & Continuous & - & 0.03 & Bailey et al. (1998) \\
\hline Single-sludge & Continuous & 12 & 0.06 & Nyberg et al. (1992) \\
\hline Single-sludge & Continuous & - & 0.06 & Kang et al. (1992) \\
\hline Single-sludge & Continuous & 30 & 0.14 & Teichgräber and Stein (1994) \\
\hline Two-sludge & Batch & $23 \pm 3$ & 0.13 & Bilanovic (1999) \\
\hline Two-sludge & Feedbatch & $22 \pm 2$ & 0.16 & Doyle et al. (2001) \\
\hline \multirow{2}{*}{ Two-sludge } & Batch & $20 \pm 0.5$ & 0.18 & This study \\
\hline & & $25 \pm 0.5$ & 0.28 & \\
\hline $\begin{array}{l}\text { Denitrifying } \\
\text { pure culture }\end{array}$ & Batch & 25 & 1.3 & $\begin{array}{l}\text { Timmermans and } \\
\text { Van Haute (1983) }\end{array}$ \\
\hline $\begin{array}{l}\text { Denitrifying } \\
\text { pure culture }\end{array}$ & Batch & 25 & 2.2 & Christensson et al. (1994) \\
\hline
\end{tabular}


TABLE 3

Batch runs to determine the MDR at six different temperatures

\begin{tabular}{|c|c|c|c|c|c|c|c|}
\hline \multirow{3}{*}{$\begin{array}{l}\text { Tempera- } \\
\text { ture }\left({ }^{\circ} \mathrm{C}\right)\end{array}$} & \multirow{2}{*}{\multicolumn{2}{|c|}{$\frac{\left[\mathrm{N}-\mathrm{NO}_{3}{ }^{-}\right]\left(\mathrm{mg} \cdot \ell^{-1}\right)}{\text { time }}$}} & \multirow{2}{*}{\multicolumn{2}{|c|}{$\frac{\operatorname{COD}\left(\mathrm{mg} \cdot \ell^{-1}\right)}{\text { time }}$}} & \multirow{3}{*}{$\begin{array}{l}\text { VSS }_{\text {average }} \\
\left(\mathrm{mg} \cdot \ell^{-1}\right)\end{array}$} & \multirow{3}{*}{\multicolumn{2}{|c|}{$\begin{array}{l}\text { MDR } \text { MDR }_{\text {average }} \\
\left(\mathrm{mgN} \cdot \mathrm{mgVSS}^{-1} \cdot \mathrm{d}^{-1}\right)\end{array}$}} \\
\hline & & & & & & & \\
\hline & $\mathbf{O h}$ & $24 \mathrm{~h}$ & $\mathrm{Oh}$ & $24 \mathrm{~h}$ & & & \\
\hline \multirow[t]{4}{*}{$25 \pm 0.5$} & 1140 & 160 & 4010 & 1130 & 3600 & 0.272 & $0.28 \pm 0.03$ \\
\hline & 1050 & 180 & 4370 & 1500 & 3600 & 0.242 & \\
\hline & 1760 & 470 & 5830 & 1870 & 4000 & 0.323 & \\
\hline & 1400 & 300 & 5530 & 2200 & 4000 & 0.275 & \\
\hline \multirow[t]{4}{*}{$20 \pm 0.5$} & 1320 & 110 & 4420 & 1030 & 4600 & 0.263 & $0.18 \pm 0.06$ \\
\hline & 1880 & 1400 & 6950 & 5570 & 4100 & 0.117 & \\
\hline & 1360 & 720 & 4490 & 2740 & 4300 & 0.149 & \\
\hline & 1400 & 560 & 6570 & 3760 & 4300 & 0.195 & \\
\hline \multirow[t]{4}{*}{$15 \pm 0.5$} & 1030 & 530 & 4580 & 2470 & 4000 & 0.125 & $0.12 \pm 0.03$ \\
\hline & 1160 & 550 & 5050 & 2750 & 4000 & 0.153 & \\
\hline & 1140 & 580 & 5430 & 3380 & 4000 & 0.140 & \\
\hline & 950 & 620 & 3990 & 2740 & 4100 & 0.080 & \\
\hline \multirow[t]{4}{*}{$10 \pm 0.5$} & 1000 & 780 & 5150 & 4370 & 3200 & 0.069 & $0.07 \pm 0.01$ \\
\hline & 1090 & 840 & 5080 & 4110 & 3600 & 0.069 & \\
\hline & 780 & 490 & 4370 & 3010 & 3300 & 0.088 & \\
\hline & 840 & 610 & 4110 & 3020 & 3800 & 0.061 & \\
\hline \multirow[t]{4}{*}{$8 \pm 0.5$} & 1060 & 840 & 4240 & 3400 & 4400 & 0.050 & $0.044 \pm 0.005$ \\
\hline & 710 & 520 & 4580 & 3840 & 4800 & 0.040 & \\
\hline & 680 & 480 & 3870 & 3070 & 4900 & 0.041 & \\
\hline & 933 & 720 & 4190 & 3420 & 4500 & 0.047 & \\
\hline \multirow[t]{4}{*}{$6 \pm 0.5$} & 1210 & 1170 & 6140 & 5890 & 4700 & 0.009 & $0.020 \pm 0.009$ \\
\hline & 1350 & 1210 & 7000 & 6240 & 4600 & 0.030 & \\
\hline & 990 & 920 & 5630 & 5470 & 4300 & 0.016 & \\
\hline & 1090 & 990 & 6970 & 6630 & 4300 & 0.023 & \\
\hline
\end{tabular}

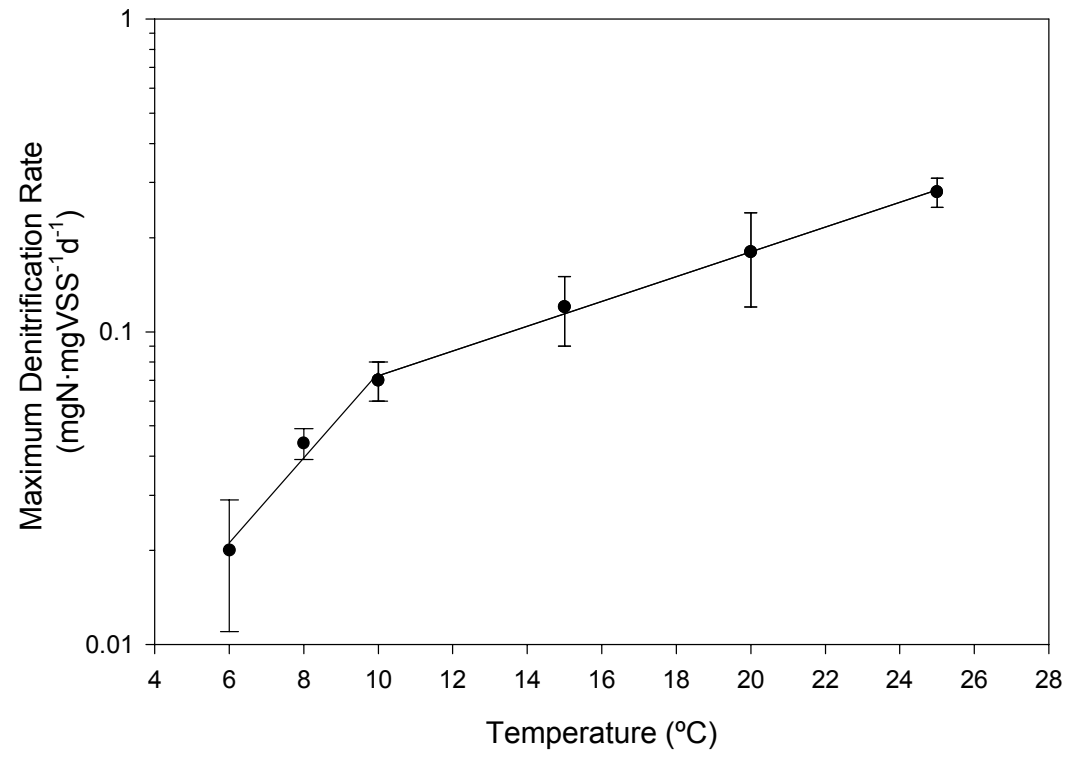

Figure 2

Effect of temperature on the denitrification rate the biomass concentration and the denitrification rate at the design temperature:

$$
H R T=\frac{\left[\mathrm{N}-\mathrm{NO}_{3}{ }^{-}\right]_{\text {removed }}}{[\mathrm{VSS}]_{\text {reactor }} \cdot r_{D, T}}
$$

where:

$$
\begin{aligned}
H R T= & \text { hydraulic retention time, days } \\
r_{D, T}= & \text { denitrification rate at temperature } \\
& \text { of design, } \\
& \mathrm{mg} \mathrm{N}-\mathrm{NO}_{3}^{-} \cdot \mathrm{mg} \mathrm{VSS}^{-1} \cdot \mathrm{d}^{-1}
\end{aligned}
$$

The correlation between the HRT and the temperature can be represented by a decay exponential function $\left(r^{2}=0.99\right)$ as shows the figure 3 (assuming that the removed nitrate concentration is $1000 \mathrm{mg} \mathrm{N}-\mathrm{NO}_{3} \cdot \ell^{-1}$, the denitrification rate is not limited by substrate and the biomass concentration in the reactor is $\left.4000 \mathrm{mg} \mathrm{VSS} \cdot \ell^{-1}\right)$. The dependency of HRT on the temperature is represented by Eq. 5: 
Figure 3

Effect of the temperature on the HRT

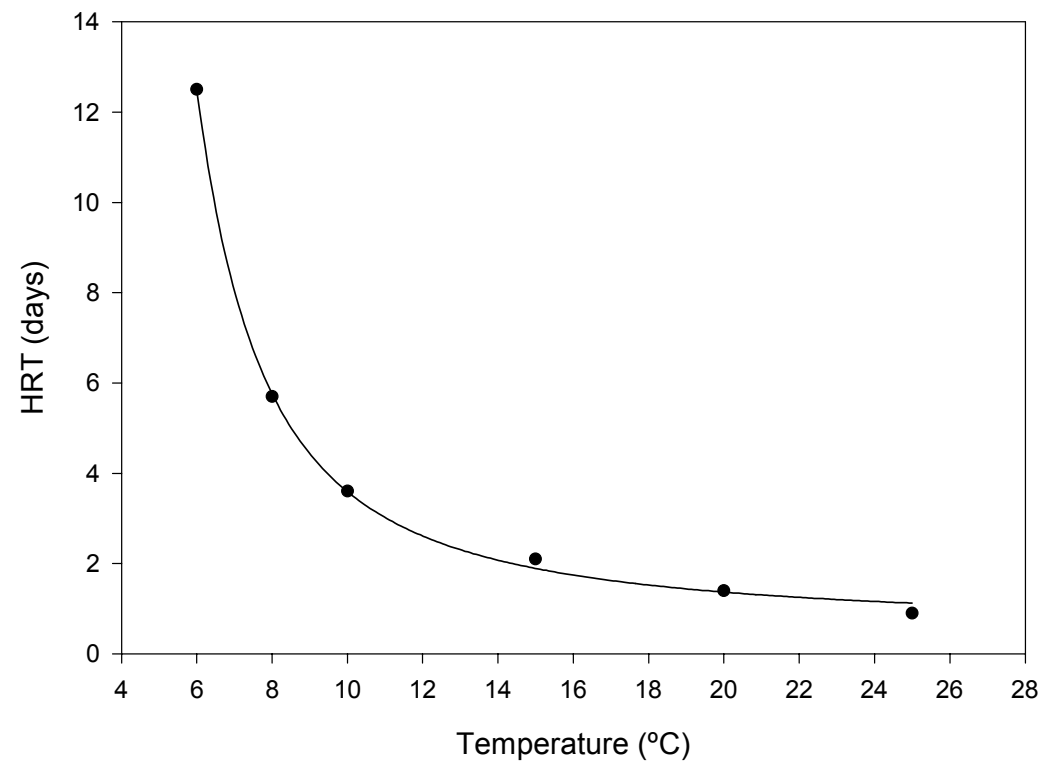

BARLINDHAUG J and ODEGAARD H (1996) Thermal hydrolysate as a carbon source for denitrification. Water Sci. Technol. 33 (12) 99-108.

BILANOVIC D, BATTISTONI P, CECCHI F, PAVAN P and MATAALVAREZ J (1999) Denitrification under high nitrate concentration and alternating anoxic conditions. Water Res. 33 (15) 3311-3320.

where:

$T=$ temperature $\left({ }^{\circ} \mathrm{C}\right)$

The predicted HRT is 11 times higher at $6^{\circ} \mathrm{C}$ than $25^{\circ} \mathrm{C}$ and 3 times higher at $10^{\circ} \mathrm{C}$ than $25^{\circ} \mathrm{C}$. These results indicate the significance of the determination of the minimum temperature on the design of the denitrifying stage of a two-sludge system.

\section{Conclusions}

The denitrification rates obtained with the two-sludge system studied are higher than those found in the literature for singlesludge and two-sludge systems using a similar carbon source.

The temperature has an important effect on the denitrification rate of a two-sludge system. The temperature coefficient is 1.10 for the range of temperatures between 10 to $25^{\circ} \mathrm{C}$ and 1.37 for the range between 6 to $10^{\circ} \mathrm{C}$.

\section{Acknowledgements}

This work has been supported by CICYT (project REN2000-0670/ TECNO). The Generalitat de Catalunya provided financial support for Julián Carrera through a pre-doctoral fellowship. We wish to express our gratitude to the company FREIXENET SA.

\section{References}

AKUNNA JC, BIZEAU C and MOLETTA R (1993) Nitrate and nitrite reductions with anaerobic sludge using various carbon sources: glucose, glycerol, acetic acid, lactic acid and methanol. Water Res. 27 (8) 13031312.

ANDERSSON B, ASPERGREN H, NYBERG U, LA COUR JANSEN J and ODEGAARD H (1998) Increasing the capacity of an extended nutrient removal plant by using different techniques. Water Sci. Technol. 37 (9) 175-183.

BAILEY W, TESFAYE A, DAKITA J, McGRATH M, DAIGGER G, BENJAMIN A and SADICK T (1998) Large-scale nitrogen removal demonstration at the Blue plains wastewater treatment plant using post-denitrification with methanol. Water Sci. Technol. 38 (1) 79-86.
CARRERA J (2001) Biological Nitrogen Removal in a High-Strengh Ammonium Industrial Wastewater. Study of the Operational Parameters and Design of a Full-Scale Treatment Plant. Ph.D. Thesis, Dept. of Chem. Eng., Univers. Autònoma de Barcelona (in Spanish).

CHEVRON F, DEFIVES C. and DUBOURGUIER HC (1997) Denitrification of high nitrate and ammonia waters using fixed-biofilms reactors on natural supports. Environ. Technol. 18 171-178.

CHRISTENSSON M, LIE E and WELANDER T (1994) A comparison between ethanol and methanol as carbon sources for denitrification. Water Sci. Technol. 30 (6) 83-90.

CONSTANTIN H and FICK M (1997) Influence of C-sources on the denitrification rate of high-nitrate concentrated industrial wastewater. Water Res. 31 (3) 583-589.

DOYLE J, WATTS S, SOLLEY D and KELLER J (2001) Exceptionally high-rate nitrification in sequencing batch reactors treating hig ammonia landfill leachate. Water Sci. Technol. 43 (3) 315-322.

EPA (1993) Manual: EPA/625/R-93/010Nitrogen Control. US EPA Office Tech. Transfer, Washington, DC.

HASSELBLAD S and HALLIN S (1998) Intermittent addition of external carbon to enhance denitrification in activated sludge. Water Sci. Technol. 37 (9) 227-233.

HENZE M (1991) Capabilities of biological nitrogen removal processes from wastewater. Water Sci. Technol. 23 (4-6) 669-679.

KANG SJ, BAILEY WF and JENKINS D (1992) Biological nutrient removal at the Blue plains wastewater treatment plant in Washington, DC. Water Sci. Technol. 26 (9-11) 2233-2236.

MATEJU V, CIZINSKA S, KREJCI J and JANOCH T (1992) Biological water denitrification - A review. Enzyme Microb. Technol. 14 170-183.

NYBERG U, ANDERSSON B and ASPERGREN H (1996) Long-term experiences with external carbon sources for nitrogen removal. Water Sci. Technol. 33 (12) 109-116.

NYBERG U, ASPERGREN H, ANDERSSON B, JANSEN J la C and VILLADSEN IS (1992) Full-scale application of nitrogen removal with methanol as carbon source. Water Sci. Technol. 26 (5-6) 10771086.

OH J and SILVERSTEIN J (1999) Oxygen inhibition of activated sludge denitrification. Water Res. 33 (8) 1925-1937.

OLESZKIEWICZJA and BERQUIST SA (1988) Low temperature nitrogen removal in sequencing discontinuos reactors. Water Res. 22 (9) 11631171.

ORHON D, GENCELI EA and SÖZEN S (2000) Experimental evaluation of the nitrification kinetics for tannery wastewaters. Water SA 26 (1) 43-50. 
SISONNF, HANAKIK and MATSUOT(1995)High loading denitrification by biological activated carbon process. Water Res. 29 (12) 2776-2779.

STANDARD METHODS (1995) Standard Methods for the Examination of Water and Wastewater (19th edn.) American Publishers Health Association.
TEICHGRABER B and STEIN A (1994) Nitrogen elimination from sludge treatment reject water-comparison of the steam-absortion and denitrification processes. Water Sci. Technol. 30 (6) 41-51.

TIMMERMANS P and VAN HAUTE A (1983) Denitrification with methanol. Fundamental work of the growth and denitrification capacity of Hyphomicrobium sp. Water Res. 17 (10) 1249-1255. 